\title{
Improving the Mechanism of State Support of Agricultural Producers
}

\author{
Shamin A.* \\ Nizhny Novgorod State Engineering and Economic \\ University \\ Knyaginino, Russia \\ E-mail: ekfakngiei@yandex.ru
}

\author{
Frolova O. \\ Institute of Economics and Management \\ Nizhny Novgorod State Engineering and Economic University \\ Knyaginino, Russia \\ E-mail: ekfakngiei@yandex.ru
}

\section{Makarychev V.}

Department of Federal Service for Veterinary and Phytosanitary Surveillance in Nizhny Novgorod region and the Republic of Mari El

Russia

E-mail: makarnn@ rambler.ru

\author{
Mitin A. \\ Institute of Economics and Management \\ Nizhny Novgorod State Engineering and Economic University \\ Knyaginino, Russia \\ E-mail: ngiei@yandex.ru
}

\begin{abstract}
The purpose of this paper is to define and propose the mechanism of state support of agricultural producers as an element of subsystem of agricultural development in modern conditions of digital transformation of agricultural and industrial industry. The research was based on the works of both domestic and foreign scientists on theoretical and practical aspects of state support, as well as normative documents revealing state and target agricultural development programs. General scientific methods and techniques as scientific abstraction, analysis and synthesis, methods of grouping and comparison were used in the process of writing of this paper. The main directions and measures of state support for both medium and small agricultural producers in Russia and foreign countries were considered in this research paper, as well as analyze of systems for allocating state support in foreign countries from methodological point of view was performed. The authors also consider the possibility of digital technologies in the context of post-pandemic transformation of economy in agricultural sectors of Russia. There is an urgent need to solve the current problems of the country's agriculture, as the most vulnerable sector in the current situation on the Russian agricultural market, in order to strengthen the positive dynamics of the development of the agricultural sector. In the context of pandemic, the inability of agricultural sector to digital transformation is most acutely felt, which creates threats and challenges in ensuring the country's food security and undermining the country's social sphere. The analysis of measures and programs of state support in Russia and foreign countries leads to the conclusion that there is an increasing need to change the approach to the mechanism of state support, because to obtain a positive lever for the development of agriculture in the country, it must be targeted and systematic. It is important to note that today the issue of providing state
\end{abstract}

support to agricultural and industrial industry doesn't lose its urgency, as the food security of the country remains the key point in determining not only the financial component of the economy as a whole, but also the social aspect in modern economic conditions. The authors presented the mechanism of state support for agriculture at the regional level, highlighted the main aspects that need to be paid attention to in the distribution of state support in the regions of Russia.

Keywords - state support, agriculture, digitalization, state regulation, mechanism of state support, post-pandemic transformation of agriculture.

\section{INTRODUCTION}

In modern market conditions, in recent years the Russian Federation has seen significant changes in almost all areas of activity, namely, the political, economic, and social life of the state.

The adoption of the State program for the development of agriculture and regulation of markets for agricultural products, raw materials and food for 2013-2020 (approved by decree of the Government of the Russian Federation from 14.07.2012 № 717 [2]) allowed defining the goals, main directions for the development of industry and markets regulation for agricultural products, raw materials and food for the mediumterm period, target indicators and forecast of agricultural development. The main directions of state support, according to the state program for the development of agriculture of the country, are presented in table 1. 
TABLE I. MODERN DIRECTIONS OF STATE SUPPORT FOR AGRICULTURE IN THE RUSSIAN FEDERATION

\begin{tabular}{|c|c|c|}
\hline \multirow[t]{3}{*}{ No. } & \multicolumn{2}{|c|}{$\begin{array}{c}\text { Directions of state support in accordance with the state program for the development of agriculture and regulation of markets for agricultural } \\
\text { products, raw materials and food for 2013-2020 }\end{array}$} \\
\hline & Support measures & Normative regulation \\
\hline & \multicolumn{2}{|c|}{ 1. Development of agricultural and industrial sectors } \\
\hline & $\begin{array}{l}\text { Stimulating the development of } \\
\text { priority sub-sectors of agricultural } \\
\text { and industrial complex and small } \\
\text { businesses }\end{array}$ & $\begin{array}{l}\text { 1. Appendix } 8 \text { to decree of the Government of the Russian Federation from 14.07.2012 № } 717 \text { "About the State program } \\
\text { of development of agriculture and regulation of markets for agricultural products, raw materials and food" (in an edition } \\
\text { from 18.12.2019 № 1706) } \\
\text { 2. Order of the Ministry of Agriculture of the Russian Federation from 20.12.2019 № } 713 \text { "About defining of priority } \\
\text { directions of development of agricultural and industrial complex in regions of the Russian Federation for } 2020 \text { " } \\
\text { 3. Resolution of the Government of the Russian Federation from } 05.02 .2020 \text { № } 86 \text { "About the approval of Rules of } \\
\text { granting and distribution of subsidies from the federal budget to regional budgets of the Russian Federation for } \\
\text { stimulating an increase in the production of oil crops" }\end{array}$ \\
\hline & $\begin{array}{l}\text { Support for agricultural production in } \\
\text { certain sub-sectors of crop and } \\
\text { livestock }\end{array}$ & $\begin{array}{l}\text { 1. Appendix } 7 \text { to decree of the Government of the Russian Federation from 14.07.2012 № } 717 \text { "About the State } \\
\text { program of development of agriculture and regulation of markets for agricultural products, raw materials and } \\
\text { food" (in an edition from 18.12.2019 № 1706) }\end{array}$ \\
\hline & \multicolumn{2}{|c|}{ 2. Promotion of investment activity in agricultural and industrial complex } \\
\hline & $\begin{array}{l}\text { Support for investment crediting in } \\
\text { agricultural and industrial sector }\end{array}$ & $\begin{array}{l}\text { Resolution of the Government of the Russian Federation from } 06.09 .2018 \text { №1063 "About granting and } \\
\text { distribution of other interbudgetary transfers from the federal budget to regional budgets of the Russian Federation } \\
\text { for compensating of part of the costs of interest on investment loans (loans) in agricultural and industrial } \\
\text { complex" (in edition from 18.09.2019 № 1209) }\end{array}$ \\
\hline & $\begin{array}{l}\text { Support for preferential crediting in } \\
\text { agricultural and industrial complex }\end{array}$ & $\begin{array}{l}\text { Order of the Ministry of Agriculture of the Russian Federation from 09.07.2019 № } 389 \text { "About the approval of the } \\
\text { list of directions for the targeted use of preferential investment loans" }\end{array}$ \\
\hline & $\begin{array}{l}\text { Compensation of part of direct costs } \\
\text { incurred for creation and/or } \\
\text { modernization of agricultural and } \\
\text { industrial complex facilities }\end{array}$ & $\begin{array}{l}\text { Resolution of the Government of the Russian Federation from } 24.11 .2018 \text { №1413 "About the approval of Rules of } \\
\text { granting and distribution of other interbudgetary transfers from the federal budget to regional budgets of the Russian } \\
\text { Federation for compensating of part of direct costs incurred for creation and/or modernization of agricultural and } \\
\text { industrial complex facilities" (in edition from 18.02.2020 № 173) }\end{array}$ \\
\hline & \multicolumn{2}{|c|}{ 3. Technical and technological modernization, innovative development } \\
\hline & $\begin{array}{l}\text { Subsidies to agricultural machinery } \\
\text { producers }\end{array}$ & $\begin{array}{l}\text { Resolution of the Government of the Russian Federation from } 27.12 .2012 \text { №1432 (in edition from 18.01.2019) } \\
\text { "About the approval of Rules of granting subsidies to agricultural machinery producers" }\end{array}$ \\
\hline & \multicolumn{2}{|c|}{ 4. Development of agricultural land reclamation in Russia } \\
\hline & $\begin{array}{l}\text { Subsidies for agricultural land } \\
\text { reclamation }\end{array}$ & $\begin{array}{l}\text { The order of the Ministry of Agriculture of the Russian Federation from } 29.01 .2020 \text { № } 31 \text { "On approval of forms } \\
\text { of the documents provided by Rules of granting and distribution of subsidies from the federal budget to regional } \\
\text { budgets of the Russian Federation within realization of actions of the departmental program "Development of the } \\
\text { Russian land reclamation complex" and measures in the field of agricultural land reclamation within the Federal } \\
\text { project "Export of agricultural products" }\end{array}$ \\
\hline & \multicolumn{2}{|l|}{ 5. Integrated development of rural areas } \\
\hline & $\begin{array}{l}\text { Subsidies for improving the housing } \\
\text { conditions of citizens living in rural } \\
\text { areas }\end{array}$ & $\begin{array}{l}\text { The order of the Ministry of Agriculture of the Russian Federation from } 28.08 .2019 \text { №510 "On approval of forms of } \\
\text { documents for granting subsidies from the federal budget to regional budgets of the Russian Federation for realization } \\
\text { of the directions (subprogrammes) of the state program of the Russian Federation "Complex development of rural } \\
\text { territories" approved by the resolution of the Government of the Russian Federation May 31, 2019 № 696" }\end{array}$ \\
\hline & $\begin{array}{l}\text { Subsidies for financial support in the } \\
\text { performance of municipal } \\
\text { expenditure obligations for housing } \\
\text { construction provided under the } \\
\text { contract for the rental of housing }\end{array}$ & $\begin{array}{l}\text { The order of the Ministry of Agriculture of the Russian Federation from } 28.08 .2019 \text { №510 "On approval of forms } \\
\text { of documents for granting subsidies from the federal budget to regional budgets of the Russian Federation for } \\
\text { realization of the directions (subprogrammes) of the state program of the Russian Federation "Complex } \\
\text { development of rural territories" approved by the resolution of the Government of the Russian Federation May 31, } \\
2019 \text { № 696" }\end{array}$ \\
\hline & $\begin{array}{l}\text { Subsidies for the development of } \\
\text { engineering infrastructure and the } \\
\text { improvement of places located in } \\
\text { rural areas for compact housing } \\
\text { development }\end{array}$ & $\begin{array}{l}\text { 1. The order of the Ministry of Agriculture of the Russian Federation from } 28.08 .2019 \text { № } 510 \text { "On approval of forms of } \\
\text { documents for granting subsidies from the federal budget to regional budgets of the Russian Federation for realization of } \\
\text { the directions (subprogrammes) of the state program of the Russian Federation "Complex development of rural territories" } \\
\text { approved by the resolution of the Government of the Russian Federation May 31,2019 № 696" } \\
\text { 2. The order of the Ministry of Agriculture of Russia from 05.09.2019 №526 "About the approval of limit values of total } \\
\text { cost and number of projects for the development of the engineering infrastructure and improvement of places located in } \\
\text { rural areas under compact housing building and projects of complex arrangement of places under compact housing } \\
\text { building in rural territories» }\end{array}$ \\
\hline & $\begin{array}{l}\text { Assistance to agricultural producers } \\
\text { working in rural areas in providing } \\
\text { qualified specialists }\end{array}$ & $\begin{array}{l}\text { The order of the Ministry of Agriculture of the Russian Federation from } 28.08 .2019 \text { № } 510 \text { "On approval of forms of } \\
\text { documents for granting subsidies from the federal budget to regional budgets of the Russian Federation for realization of the } \\
\text { directions (subprogrammes) of the state program of the Russian Federation "Complex development of rural territories" } \\
\text { approved by the resolution of the Government of the Russian Federation May 31, } 2019 \text { № } 696 \text { " }\end{array}$ \\
\hline & $\begin{array}{l}\text { Subsidies for implementation of } \\
\text { integrated rural development projects }\end{array}$ & $\begin{array}{l}\text { 1. The order of the Ministry of Agriculture of the Russian Federation from 18.10.2019 № } 588 \text { "On approval of the } \\
\text { Procedure for developing and selecting projects for integrated rural development (rural agglomerations)" } \\
\text { 2. The order of the Ministry of Agriculture of the Russian Federation from 28.08.2019 № } 510 \text { "On approval of forms } \\
\text { of documents for granting subsidies from the federal budget to regional budgets of the Russian Federation for } \\
\text { realization of the directions (subprogrammes) of the state program of the Russian Federation "Complex development } \\
\text { of rural territories" approved by the resolution of the Government of the Russian Federation May 31, } 2019 \text { № 696" }\end{array}$ \\
\hline & stavismment of su & ners and development of rural cooperation \\
\hline & & $\begin{array}{l}\text { The order of the Ministry of Agriculture of the Russian Federation from } 28.01 .2020 \text { № } 26 \text { "About the approval of lists, } \\
\text { forms of the documents provided by the Rules of granting and distribution of subsidies from the federal budget to regional } \\
\text { budgets of the Russian Federation on establishment of support system for farmers and development of rural cooperation" } \\
\text { provided in appendix № } 6 \text { to State program of development of agriculture and regulation of the markets of the agricultural } \\
\text { products, raw materials and food approved by the resolution of the Government of the Russian Federation from } \\
14.07 .2012 \text { № } 717\end{array}$ \\
\hline
\end{tabular}

${ }^{\text {a. }}$ Source: compiled by the author based on the analysis of measures of state support for agriculture of the Russian Federation. 


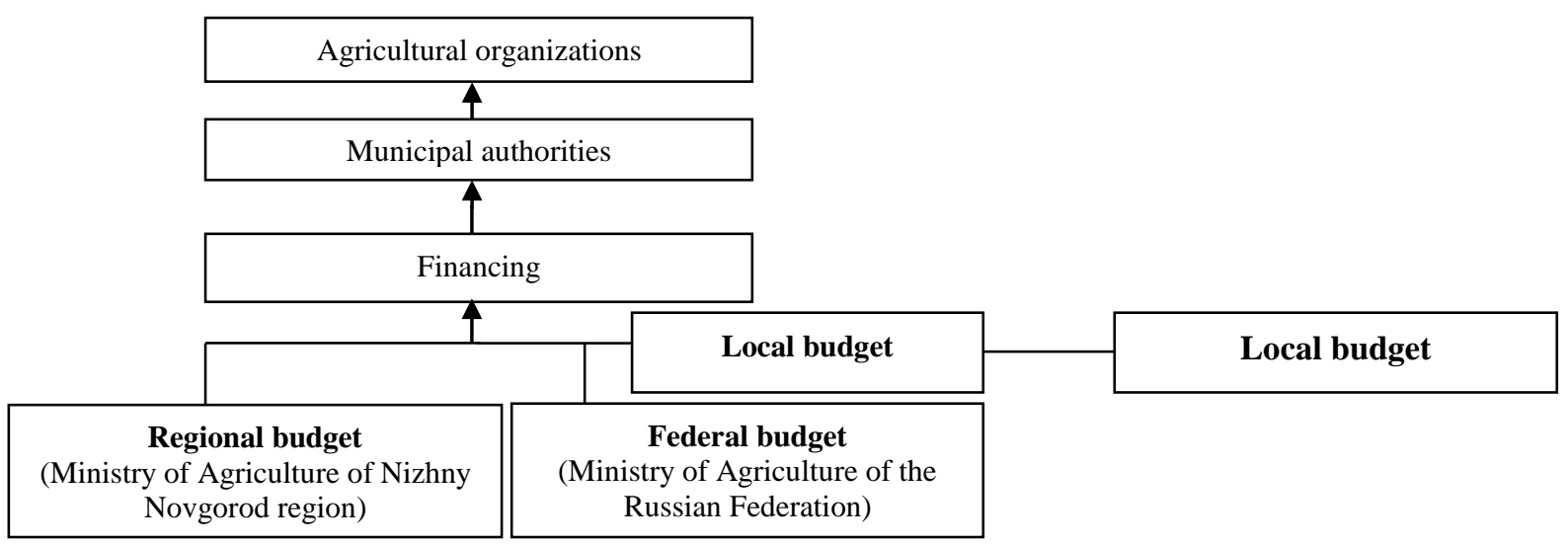

Fig. 1. General mechanism of state support for agriculture (Source: compiled by the author based on the results of research)

\section{MATERIALS AND METHODS}

Considering the peculiarities of state regulation of agriculture as an industry of unique character, it is important to take into account the directions of state support of agricultural producers in the conditions of modern framework and challenges from external factors.

Thus, it should be noted that the development and adoption of the State program for the development of agriculture and regulation of markets for agricultural products, raw materials and food for 2013-2020 served as a kind of impetus for the development of both the agricultural sector and related indicators, specifically the social sphere and rural development, which is necessary for obtaining a positive result in the regulation of the agricultural sector of the country and regions (in particular) [2]

In the system of state regulation and support, regional features are taken into account in the implementation of target programs.

The general type of the mechanism of state support for agriculture at the regional level is as follows: funds from the federal and regional budgets are received in the form of financing of municipal district authorities, and then distributed to agricultural organizations (figure 1).

\section{RESULTS}

Taking into account the opinions of the authors from monographic sources, scientific works and articles, as well as our own monitoring, we conclude that any economic mechanism is expressed by a certain set and sequence of economic processes [15].

The scientific interest is the study of experience of implementation of state support in foreign countries.

Nowadays globalization of the world economy affects all states, determining the development and spread of technologies between countries, the use of labor, the production of goods and the supply of services, and investment [16]. Thus Russia's accession to WTO has led to the aggravation of systemic problems in agrarian sphere, specifically the amount of received income is not sufficient to compensate for production costs, land conservation and social development of rural areas. It should be noted that the indicators of agricultural production in foreign countries exceed similar domestic indicators. The European Union (accounting for 11 per cent of world output) and the United States of America (accounting for 10 per cent of world agricultural output) are one of the leading agricultural producers now. From our point of view, one of the positive points is that all WTO member countries provide support within the framework of "baskets".

TABLE II. CLASSIFICATION OF STATE SUPPORT MEASURES FOR AGRICULTURE

\begin{tabular}{|c|c|c|}
\hline $\begin{array}{c}\text { Classification of } \\
\text { basket }\end{array}$ & $\begin{array}{l}\text { Form of } \\
\text { regulation }\end{array}$ & $\begin{array}{c}\text { Characteristic of provided } \\
\text { measures }\end{array}$ \\
\hline $\begin{array}{l}\text { Measures of } \\
\text { «yellow basket» }\end{array}$ & Direct regulation & $\begin{array}{l}\text { 1. Price regulation } \\
\text { 2. Preferential crediting } \\
\text { 3. Co-financing of capital } \\
\text { investments } \\
\text { 4. Advantages when paying } \\
\text { for gazoline, lubricants, } \\
\text { fertilizers, feed, electricity } \\
\text { 5. Subsidies for special types } \\
\text { of products }\end{array}$ \\
\hline $\begin{array}{l}\text { Measures of «green } \\
\text { basket» }\end{array}$ & Indirect regulation & $\begin{array}{l}\text { 1. Financing of scientific } \\
\text { research } \\
\text { 2. Pest and disease control } \\
\text { 3. Consulting services } \\
\text { 4. Support in case of natural } \\
\text { disasters } \\
\text { 5. Establishment of state food } \\
\text { reserves } \\
\text { 6. Preferential insurance }\end{array}$ \\
\hline $\begin{array}{l}\text { Measures of «blue } \\
\text { basket» }\end{array}$ & $\begin{array}{l}\text { Regulation of } \\
\text { outputs }\end{array}$ & $\begin{array}{l}\text { Payments linked to funded } \\
\text { areas (livestock) }\end{array}$ \\
\hline
\end{tabular}

${ }^{\text {b. }}$ Source: compiled by the author based on the results of research

In the European Union, state support for agriculture is carried out within the framework of the Unified Agricultural Policy (UAP), which has five main directions: increasing productivity in agriculture; market stabilization; uninterrupted delivery of food; ensuring decent standard of living for farmers; ensuring reasonable prices for consumers [7]. 
In modern conditions Russia is making a transition that allows rejecting a direct impact measures. Therefore, there is a need for smooth and gradual development of mechanism for indirect regulation of industry, specially the use of indirect measures (introduction of digital technologies into industry, development of rural areas, support of innovative development) in order to protect domestic agricultural producers from imported products and ensure food security of the country.

The world leaders in this area are the United States, China, South Korea, Singapore, Germany, Sweden (table 3). Analysts of the consulting company BCG predict that the volume of the global digital economy in the world will reach 16 billion dollars by 2035. A significant portion of the total volume will come from the United States of America. Today the share of the digital economy in US GDP exceeds $10.9 \%$, in Europe this indicator is $5.0 \%$ [6].

It is important to note that the share of Russia's digital economy is gaining momentum, although it is not in the lead (behind the United States, China, Great Britain, Germany, Italy and Sweden) [4]. The implementation of digital solutions in agricultural and industrial complex is a boost that will help to increase the efficiency on different stages of agriculture and thereby to reduce the influence of the human factor (which can serve as the main trigger for the development of agriculture), and therefore to increase the competitiveness of agricultural producers of the country and regions (in particular).

TABLE III. SHARE OF DIGITAL ECONOMY DEVELOPMENT INDICATORS IN GDP OF SOME COUNTRIES FOR 2017,\%

\begin{tabular}{|c|c|c|c|c|c|c|c|}
\hline \multirow{2}{*}{$\begin{array}{c}\text { Indicators of } \\
\text { digital } \\
\text { economy } \\
\text { development }\end{array}$} & \multicolumn{7}{|c|}{ Countries } \\
\hline & 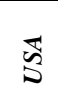 & Ð & $\begin{array}{c}\text { Great Britain, } \\
\text { Germany, Italy, } \\
\text { Sweden (in average) }\end{array}$ & $\Xi$ & 芯 & 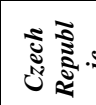 & 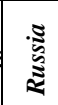 \\
\hline $\begin{array}{l}\text { Population } \\
\text { expenses in } \\
\text { digital } \\
\text { environment }\end{array}$ & 5.3 & 4.8 & 3.7 & 3.2 & 2.7 & 2.2 & 2.6 \\
\hline $\begin{array}{l}\text { Business } \\
\text { investments in } \\
\text { digital economy }\end{array}$ & 5.0 & 1.8 & 3.9 & 2.7 & 3.6 & 2.0 & 2.2 \\
\hline $\begin{array}{l}\text { State expenses } \\
\text { on digital } \\
\text { economy }\end{array}$ & 1.3 & 0.4 & 1.0 & 0.6 & 0.8 & 0.5 & 0.5 \\
\hline Export of ICT & 1.4 & 5.8 & 2.5 & 5.9 & 0.1 & 2.9 & 0.5 \\
\hline Import of ICT & -2.1 & -2.7 & -2.9 & -6.1 & -1.0 & -2.1 & -1.8 \\
\hline $\begin{array}{l}\text { Amount of } \\
\text { digital economy }\end{array}$ & 10.9 & 10.0 & 8.2 & 6.3 & 6.2 & 5.5 & 3.9 \\
\hline
\end{tabular}

c. Source: compiled by the author based on the results of research

\section{DISCUSSION}

If we consider state regulation in terms of the set of positions of system, which clearly represents an open object and consists of several subsystems: the first is related to access of agricultural producer (both medium and small) to the market and business; the second is directly represented by measures of state support for agriculture and the third directly covers the social and economic development of rural areas. In this regard, the system of provided measures (the mechanism of state support for agriculture) should have the ability not just to adapt, but to have a well-structured algorithm, which will allow resisting the challenges of external environment, causing new relationships that affect the producers' activities.

Researchers conducted in the field of forming the system of state regulation of Russian agriculture has revealed the inefficiency of the mechanism in the context of economic transformation, because as a result, the state support is mainly provided to enterprises that are able to self-sustain themselves.

In our opinion, the main component of the mechanism of state support for agriculture should be the system of financing unprofitable producers, with monitoring of the effectiveness of agricultural organizations taking into account the allocated state support (figure 2).

We propose to allocate state support to unprofitable enterprises, at the same time making contracts and checking the existence of valid agreement on medium-term financing of unprofitable farms for 3 years. Total state support should be provided only to those agricultural organizations that have concluded this agreement. Agricultural organizations supported by the Government operate in the same manner. Each year, based on the results of their activities, the effectiveness of agricultural organizations is monitored taking into account provided state support, the results of which are sent in the form of reports to the control body of audit. Based on the results of monitoring, state funds are distributed to agricultural organizations.

This mechanism corresponds to the modern conditions of the country's agriculture development, will contribute to the rational use of state funds, and guarantees the comprehensive support to economic producers.

\section{CONCLUSION}

State support for agricultural producers should be considered from the point of view of fundamental function of state regulation of agriculture. Nowadays the Russian Federation has developed a multi-layered agrarian economy, represented by various forms of farms (agricultural holdings, agricultural organizations, private farms and family farms). They have occupied a certain niches in agricultural sector, have some development reserves. But despite this, it is important to take into account modern trends, specially the development of digital economy (transformation of agriculture in the country) in order to increase production and ensure food independence both of regions and of the country.

In the methodology there are several fundamentally different approaches to planning state support for agriculture. Briefly they are based on the following principles: contribution of industry to GDP formation, comparison with the level of agricultural support in developed countries, restoration and maintenance of intersectoral parity of prices and incomes, determining the need for subsidies for certain types of agricultural activities. This method is based on a common approach - ensuring conditions of reproduction and necessary profitability for specific agricultural enterprises. In this regard, a certain mechanism is needed that allows rational use of budget funds for the implementation of state programs. Nowadays within the framework of post-pandemic, one of the 
main complex tasks of the state is to make agriculture digital and promising.

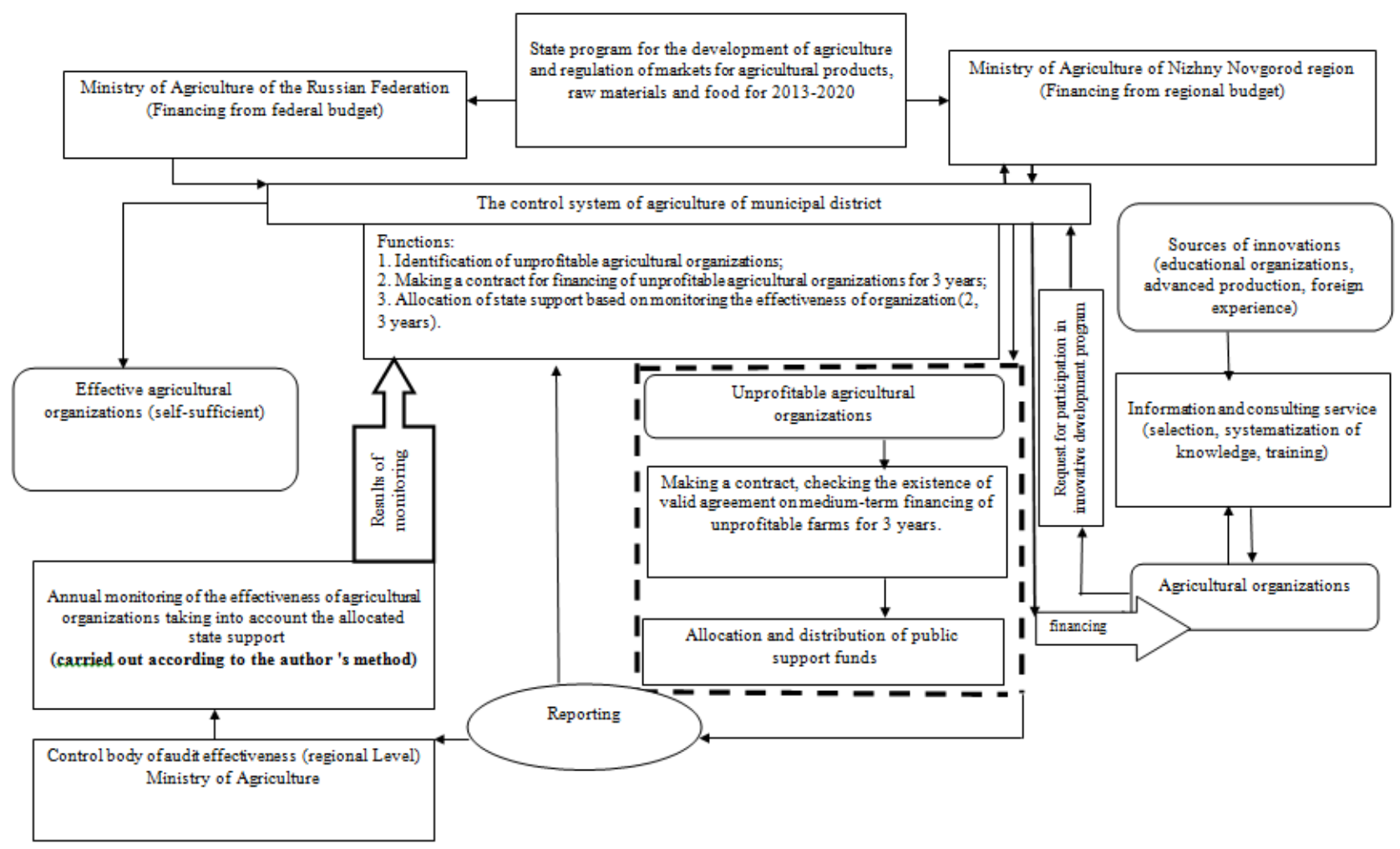

Fig. 2. Improved mechanism of state support for agriculture at regional level

\section{References}

[1] "Digital Agriculture", Departmental project, official publication. Moscow: Rosinformagrotech, 2019, 48 p.

[2] State programme "Development of agriculture and regulation of markets for agricultural products, raw materials and food for 2013-2020", approved by decree of the Government of the Russian Federation from 14.07.2012, no. 717 .

[3] E.N. Krylatykh, V.I. Nazarenko, A.G. Paptsov, O.I. Panteleeva et al., Agrarian Europe in XXI Century, The Institute of Europe of the Russian Academy of Sciences. Moscow, 2015.

[4] New technologies: India, China, Brazil and others, AgroXXI.ru Agricultural and industrial portal. Moscow: Listerra Publishing House, 1995-2019. Retrieved from: https://www.agroxxi.ru/gazeta-zaschitarastenii/zrast/novye-tehnologii-indija-kitai-brazilija-i-drugie-strany.html

[5] Europe proposes to double the research budget in the field of digitalization of agricultural sector in the period 2021-2027. AgroXXI.ru Agricultural and industrial portal. Moscow: Listerra Publishing House, 1995-2019. Retrieved from: https://www.agroxxi.ru/mirovye-agronovosti/evropapredlagaet-udvoit-byudzhet-issledovanii-v-oblasti-cifrovizacii-agrosektorav-period-2021-2027.html

[6] L.N. Usenko, O.A. Kholodov, "Digital transformation of agriculture", Account. and statist., vol. 1, no. 53, pp. 87-102, 2019.

[7] R.M. Kotov, "Comparative characteristics of systems of state regulation and support of agriculture in foreign countries", Transact. of sci. papers of the Novosibirsk state techn. Univer., vol. 3, no. 49, pp. 113-118, 2007. Novosibirsk.

[8] M. Odening, Z. Shen, "Challenges of insuring weather risk in agriculture", Agricult. Finance Rev., vol. 74, no. 2, pp. 188-199, 2014.

[9] M. Söderström, K. Piikki, M. Stenberg, H. Stadig, J. Martinsson, "Producing nitrogen $(\mathrm{N})$ uptake maps in winter wheat by combining proximal crop measurements WITH SENTINEL-2 and DMC satellite images in a decision support system for farmers", Acta Agricult.
Scandinavica. Sect. B: Soil and Plant Sci., vol. 67, no. 7, pp. 637-650, 2017.

[10] J. Jayanth, V.S. Shalini, Kumar T. Ashok, S. Koliwad, Classification of Field-Level Crop Types with a Time Series Satellite Data Using Deep Neural Network, In: Hemanth D. (ed.) Artificial Intelligence Techniques for Satellite Image Analysis. Remote Sensing and Digital Image Processing, vol. 24. Springer, Cham, 2020.

[11] V.V. Maslova, N.F. Zaruk, K. Fuchs, M.V. Avdeev, "Competitiveness of agricultural products in the eurasian economic union", Agricult., vol. 9, no. 3, pp. 7, 2019.

[12] L. Zhang, S. Chen, "China's Digital Economy: Opportunities and Risks", Int. Organisat. Res. J., vol. 14, no. 2, pp. 275-303, 2019. DOI: 10.17323/1996-7845-2019-02-11

[13] R. Bukht, R. Heeks, "Defining, Conceptualising and Measuring the Digital Economy", Int. Organisat. Res. J., vol. 13, no. 2, pp. 143-172, 2018. DOI: 10.17323/1996-7845-2018-02-07.

[14] N.V. Sharapova, Mechanism of support of agricultural producers in system of state regulation of industry: theory, methodology, practice. Moscow: Fund "Personnel reserve", 2019, 300 p.

[15] A. Shamin, O. Frolova, V. Makarychev et al., "Digital transformation of agricultural industry", IOP Conf. Ser. Earth and Environmental Sci., vol. 346, p. 012029, 2019. DOI: 10.1088/1755-1315/346/1/012029.

[16] O. Dobrenkova, T. Kutaeva, D. Gorshkovaet al., Las áreasprincipales de la regulaciónestatal delasorganizacionesagrícolas: Dilemascontemporáneos: Educación, Política y Valores, 2019. 